\title{
Innovation in Hungary - The Impact of EU Accession and Integration into Global Value Chains
}

\begin{abstract}
This paper argues that EU accession has brought about minimal changes in the patterns of innovation in Hungary. The reason why is not that the 'EU factor' is of minor importance; rather, it is Hungary's inability to use EU resources effectively, so as to fully benefit from EU membership. The Hungarian story also demonstrates that the EU cannot block member states from reversing reform or abusing the opportunities EU membership offers to them. We contend that globalization (global value chain integration) has more effectively contributed to Hungary's knowledge-based upgrading than Europeanization (in the sense of policy transfer; access to EU Structural \& Cohesion Funds, and integration in the European Research Area). This argument is substantiated with a case study on innovation strategy design and implementation, which illustrates the ambiguous impact of Europeanization, which is contrasted with our investigation of integration in global value chains, conducted through interviews of foreign-owned manufacturing companies about their R\&D-based upgrading experience.
\end{abstract}

Keywords: Hungary, regional innovation policy, EU accession, global value chains, R\&Dbased upgrading JEL: O38, R58, E65

\section{Introduction}

In economies undergoing transformation, innovation stakeholders cherished high hopes for EU accession. Economic scholars have emphasized broad-based, soft factors, focusing on: 
- adoption of EU best practices, e.g., concerning the governance of innovation;

- policy transfers and regular monitoring and evaluation of national innovation policies by EU experts;

- integration of innovative actors in European (cross-border) research undertakings - as a solution to the fact that the resources of single nations are, in a growing number of research areas, below the critical mass needed to achieve breakthrough results;

- collaboration with foreign centers of excellence and enhanced opportunities for researchers' mobility; and

- access to resources of, and services offered by, an integrated European research infrastructure etc.

The expectations of local stakeholders are more closely aligned with, and restricted by, what may broadly be characterized as pecuniary considerations. Researchers concentrated upon funding instruments, such as the Research Framework and Competitiveness and Innovation Framework Programs, while innovative actors in the business or higher education spheres (particularly innovation policy-makers) anticipated that a fair share of EU Structural and Cohesion Fund resources would be dedicated to innovation purposes.

Both sets of expectations have been met, and even exceeded. Local innovation undertakings have benefitted from an unprecedented volume of funding from Structural Funds, and the soft opportunities of EU-accession have also lived up to and, at time, gone beyond the expectations of stakeholders.

\section{Methodological Difficulties of Quantifying the Impact}

Quantifying the impact of EU accession (i.e., the quantification of both inputs and outputs) presents huge methodological difficulties. In restricting our analysis to the pecuniary aspects, a preliminary question is how much EU funding Hungarian stakeholders could benefit from. According to statistics published at the New Széchenyi Plan's (Hungary's development program) website, grants paid from EU Structural Funds that co-financed innovation activities in the 2010 to 2013 period was HUF 203.8 billion ( $€ 680$ million). This amount is related to the 'Science and Innovation Program' of the New Széchenyi Plan.

Nevertheless, innovation and technology development related grants may also have been allocated to stakeholders through other Operational Programs, such as the 'Development of Business Environment,' 'Green Economy Program,' or Health Industry Programs.

Before 2010, regional innovative stakeholders could access support from Regional OPs. These programs partially co-financed regional stakeholders' R\&D and technology development activities. Changes in OPs' structure from 2010 onwards (OPs have become organized by policy priorities: they have not followed a territorial logic any more), coupled with a lack of precise data, make it difficult to accurately estimate the volume of innovation-related EU co-financed funding. 
Another estimation method is to apply the 'share of the state budget in business enterprises' R\&D investments' as a rough proxy. Data for this indicator are compiled by the Central Statistical Office. Given that EU Structural Funds have virtually substituted for national funds in Hungary (in terms of support provided to foster business enterprises' R\&D and technology development activities), this baseline proxy can adequately quantify this specific component of EU co-financed R\&D-related investments. (Another important component of innovation-specific EU-funds supports higher education institutions' research and research infrastructure development expenditures). According to Central Statistical Office data, the state budget accounted for $\sim 4 \%$ of business enterprises' total R\&D expenses in 2005 (when national funding was still available). In 2010 this indicator was 14\%; in 2012: 15.7\%.

Quantifying innovation performance poses even greater methodological problems. Langford et al. [2006] distinguished R\&D outputs from the outcomes of R\&D undertakings, classifying, e.g., invention disclosures and patents into the first category and universities' license revenues into the second category. Similarly, publications belong to the first category and new scientific methods that result from those a given publication belong to the second. A third category that analysts have to deal with is the economic impact derived from R\&D outputs: improved macroeconomic or environmental, societal etc. indicators. Spin-off creation, for example, may be classified as an outcome of R\&D undertakings, while the number of employees and total revenues generated by spin-off companies, as well as the value of university equity holdings in spin-offs, belong to the third category. Similarly, elaboration of a new process technology is an outcome of R\&D, while cost savings, improved energy efficiency, and productivity increases that result from the use of the new process technology belong to the economic impact category.

It also bears mention here that an analysis of the impact of EU accession on new member states' innovation performance may be premature. One could argue that the 2007-2013 period may be of inadequate length, since changes in a country's innovation potential become manifest only over quite a long period.

Given these significant methodological difficulties in measuring the impact of the $\mathrm{EU}$ on national innovation performance, this paper instead analyses how EU membership is manifested in science, technology and innovation (STI) policy formulation and implementation, as well as in the characteristics of the national innovation system. Since the 'Europeanization of STI policy' is a complex and diversified issue and encompasses multiple areas of public policy, we selected one specific field of Europeanization: the regionalization of innovation that 'culminated' in the drafting of regional research and innovation strategies for smart specialization.

We argue that EU accession has brought about minimal changes in the patterns of innovation in Hungary. Globalization (in the sense of global value chain integration) has more effectively contributed to Hungary's knowledge-based upgrading than Europeanization (in the sense of integration in the European Research Area; access to EU Structural \& Cohesion Funds and adoption of EU-level innovation policy principles).

The reason for the relatively minor impact of EU-membership on Hungary's knowledge-based upgrading is Hungary's poor ability and, currently, lack of commitment, to use EU 
resources effectively. These deficiencies in utilizing the opportunities of EU membership by using and leveraging EU resources to improve knowledge-based competitiveness is where the one half of the fault lies. The other half of the fault is the EU's inability to block member states from reversing reform and blatantly abusing the opportunities of EU membership.

The rest of this paper is structured in five sections. The next section (section 2) briefly summarizes the specifics of the Hungarian national innovation system (NIS), and frames our research question, which is whether EU-membership has provoked any changes in the features of the system. We compare the hard indicators used to measure the performance of the system with selected soft features that may reveal more about system efficiency improvements than the hard features.

This comparison is followed by a case study on the regionalization of innovation (section 3), which is performed to illustrate our argument that the incorporation of European procedures and policy mechanisms in the Hungarian NIS (Europeanization) pertains to the realm of 'dead letters'.

Section 5 substantiates a second finding of this paper, which is that economic actors' integration into global value chains exerted a strong influence on Hungary's innovation performance and on Hungarian actors knowledge-based upgrading. We reach this finding through interviews of fifteen local, R\&D-intensive subsidiaries of foreign manufacturing multinational companies (MNCs). The interview sample and research method are described in section 4 . Our conclusions, and resulting policy suggestions, are presented in section 6 .

\section{Characteristics of the Hungarian Innovation System}

A popular Hungarian writer, György Moldova wrote a book about the Hungarian health system entitled 'The spendthrift beggar'. The title refers to the enormous waste of resources that characterizes the Hungarian health system; the convergence of overinvestment in expensive medical instruments, hospital overcapacities, and shortages of basic resources (unpaid medicine suppliers, mediocre facilities, resource constraints for basic hospital maintenance etc.). Moldova's witty metaphor equally applies to the Hungarian NIS, which is also characterized by a low efficiency of public investment in R\&D and system-wide waste of resources.

As a matter of fact, the low efficiency of public $R \& D$ investments applies (to a varying extent) to all new EU member states. Pop et al. [2014] surveyed the relationship between private and public R\&D (intensity) and Central and Eastern European countries' (CEE) growth performance, over the 1998 to 2008 period. According to the referred author's calculations, the impact of public R\&D is statistically insignificant in practically all the surveyed CEE economies. By contrast, private R\&D (intensity increase) was found to have a significant impact on growth. 
Hungary is one of the worst performers with respect to the efficiency of public investments in innovation. Montalvo-Moghayer [2011] computed innovation system efficiency indices; that is, input/output ratios of R\&D efforts. According to their calculations, Hungary had one of the least efficient innovation systems, while the Czech Republic enjoyed the best performance among CEE economies.

Izsák et al. [2013] were concerned with the throughput of government support to business innovation. The authors analyzed the relation between the share of (1) government support to business innovation in total BERD and (2) SMEs introducing product or process innovation in $24 \mathrm{EU}$ member countries and Switzerland. They found a broad, positive association between the two factors with a few exceptions. Hungary was one of those exceptions (together with Latvia and, to some extent, Bulgaria). Although a relatively large share of total funding was devoted to support business enterprise research, technology development, and innovation efforts in these countries, the share of innovative SMEs was particularly low, reflecting a thought-provoking mismatch between policy focus and outcome.

As outlined by Havas [2007; 2011], Hungary has successfully created the necessary institutions (government bodies, financing, administrative and management agencies at various spatial levels; bridging organizations, NGOs etc.) that exist in developed economies with high-performing NISs. Hungary also employs a wide range of innovation support measures and policy schemes that target various components of the system at various stages of the innovation cycle. The amount of support allocated to foster research, development and innovation activities, together with the volume of private innovation outlays, have considerably increased over the surveyed period - as quantified by the hard indicators in table 1. Indeed, performance, as reflected by the main input indicators and as shares of public, private and foreign sources of GERD, definitely started to converge to those of established EU economies (table 1).

\section{TABLE 1. Hungary's national innovation system: evolution of some performance indicators since EU-accession}

\begin{tabular}{|l|l|c|c|}
\hline \multicolumn{1}{|c|}{ Source } & \multicolumn{1}{|c|}{ Indicator } & 2004 & 2012 \\
\hline a & GERD/GDP & 0.88 & 1.29 \\
\hline b & SII & 0.266 & 0.323 \\
\hline c & Percentage of GERD financed by industry & 37.1 & 46.9 \\
\hline c & Percentage of GERD financed by government & 51.8 & 36.9 \\
\hline a & Total employment in R\&D units & 49,615 & 56,486 \\
\hline c & Total researchers FTE & 14,904 & 23,837 \\
\hline a & Number of corporate R\&D units & 669 & 1,583 \\
\hline a & Employment in corporate R\&D units & 8,870 & 23,298 \\
\hline
\end{tabular}

S o u r c e s : a) Central Statistical Office, Hungary; b) European Innovation Scoreboard, 2008 and Innovation Union Scoreboard, 2013; c) OECD Science and Technology Indicators. 
Nevertheless, the real performance and efficiency improvement of the Hungarian NIS is barely discernible using accepted indicators. ${ }^{1}$

For example, the value of the summary innovation index (SII) has definitely increased over the surveyed period. ${ }^{2}$ Composite indicators are, however, biased upwards by Hungary's FDI-driven specialization in medium and high-technology industries. Consequently, the 'contribution of medium and high-tech product exports to the trade balance' (an important component of composite indicators), is higher than average. The value of this indicator is driven by processing exporters with low and sometimes even declining(!) local value added shares. $^{3}$

Statistical illusion with respect to the evolution of innovation performance is also reinforced by the increasing BERD-intensity of economic performance. This indicator is driven by the huge amount of support (co-financed from EU Structural Funds) allocated to $\mathrm{R} \& \mathrm{D}$-specific investments. Access to $\mathrm{R} \& \mathrm{D}$-specific support prompted companies to report R\&D activities, which amplified the improvement of this indicator, since underreporting and previously exerted a significant downward bias on the number of companies with R\&D activity [Sass, 2013].

The meagre performance of NIS is best reflected by the fact that innovation performance is still driven mainly by foreign companies. ${ }^{4}$ Indigenous companies' technology generation and, particularly, commercialization, is minimal, despite the clear focus of Hungary's STI policy on downstream, i.e., direct business R\&D [Izsák et al., 2013]. In $2010,74 \%$ of small enterprises (including foreign and domestic-owned ones) reported no innovation activity at all.

Public research institutions are still unable to convert their scientific results into commercial success, partly for lack of the necessary intangible capital and partly because of the underdeveloped market for technology. ${ }^{5}$ Public-private innovation collaboration is minimal and foreign subsidiaries rarely collaborate with indigenous companies in the field of R\&D [Sass-Szalavetz, forthcoming] - as a matter of fact public-private collaboration is more or less restricted to cases where specifically designated support is allocated to promote such collaborations.

An oft-mentioned feature of the Hungarian innovation system is that policy actors are weak and disorganized, and that coordination among them is minimal. Institutional stability is missing from the system; key institutions of innovation policy design and implementation have undergone radical reorganization in practically all political cycles [Gál, 2013]. Consequently, although strategic documents outlining the future orientation of STI policies are regularly prepared, written strategies usually remain dead letters. 


\section{Case Study on the 'Europeanization' of the Hungarian Innovation System: 'Façade Regionalism'}

When discussing the impact of EU integration on the features of Hungary's innovation system, it is necessary to distinguish between the 'opportunity aspects' of integration and the Europeanization of the system.

The opportunity aspect of EU integration derives from the possibility of emulating European best practices, which is facilitated by EU-funded institution building; institutional capacity building; improvement of the framework conditions; strategy design; and implementation. 'Opportunity' is therefore closely related to local policy learning, fostered by technical advice, and supported by experimentation and feedback mechanisms. For example, as a member of the EU community Hungarian STI policy decision-makers benefit from regular surveys of the innovation system carried out by EU experts [cf. European Commission, 2013]. These surveys are intended to identify and mitigate structural impediments in member states' innovation systems, and improve their efficiency.

'Opportunity' is a softer category than Europeanization: the latter implies an institutionalization of rules, norms, policy mechanisms and procedures, and their incorporation into the national legislative and institutional systems - as a compulsory exercise and not as an opportunity for optional emulation, learning, and improvement.

If the potential of certain systemic changes is recognized, EU-level actions can be decided upon that will, in turn, be imposed on member states - for example, as an ex-ante conditionality for access to European Structural and Cohesion Funds.

A relevant example is the reform of the EU Cohesion policy that prescribed the preparation of research and innovation strategies for smart specialization (RIS3) ${ }^{6}$ as ex-ante conditionality for supporting $R \& D$ investments. This decision reflects the recognition that different regions face different industrial and innovation policy challenges, depending on their endowments, industrial and technological specialization, distance to the technology frontier, institutional development, collaboration intensity among actors, intra- and inter-regional linkages. Hence, this decision reflects the fact that one size does not fit all [Reid, 2011].

As it will be shown, the implementation of RIS3 only appears to be an example of Europeanization: despite impeccable compliance, it actually exemplifies a missed 'opportunity' in Hungary. Drawing on the distinction made by Bachtler et al. [2013], rationalist adaptation occurred (i.e. formalistic adaptation, driven by actors' opportunistic response to incentives) rather than sociological adaptation (driven by norms of appropriate behavior and identification with the EU).

Developments were similar to what happened in the early 2000s, when the Europeanization of territorial governance (regionalization) was on Hungary's agenda. Over time, several papers have convincingly demonstrated that despite 'compliance on paper' and 
the creation of relevant territorial governance structures and institutions, the outcome of Hungary's regionalization was increased centralization [Bruszt, 2008; Pálné Kovács, 2009; 2013; Buzogány-Korkut, 2013]. These referred works detail the specifics of the Hungarian 'regionalization', marked by 'regionalism without regions', i.e., weak regional structures with little legitimacy and powerless regional actors; vested interests of regional, local and national actors; double-speak; parallelisms (with counties, i.e., NUTS3 regions); and recurring centralization waves driven partly by the recognition of anomalies in the system but also by distrust between the national and the regional-level institutions and changing values, ideologies and norms.

The recent regionalization of the innovation system has followed a similar trajectory. National innovation policies started to take the regional/spatial dimension into account following the 2003. XC. Act on the Research and Technological Innovation Fund. The act prescribed that $25 \%$ of the Fund's yearly income be designated to regional innovation purposes. Regional innovation agencies (RIAs) were founded in the mid-2000s and entrusted with designing regional innovation strategies, linkage building, and developing and providing regional innovation related services.

By the end of the 2000s, RIAs underwent substantial capacity development, accumulating region-specific (or rather regional innovation system-specific) knowledge and relational capital. However, their institutional autonomy and capacity to influence regional innovation strategy implementation kept diminishing as a result of policy-makers' repeated re-centralization moves.

The first milestone in the RIAs' roll-back was a gradual hollowing out of the regionally decentralized innovation programs. While RIAs could initially influence the content of regionally decentralized innovation support programs and include regional specifics, that function was taken back (and made centrally) by the National Innovation Office (NIO). ${ }^{7}$ According to an NIO official's comment to the author's interview questions, decentralization in the mid-2000s created a multitude of highly diversified programs that were very difficult to administer and monitor. Therefore, the RIAs' role was restricted to determining the range of strategic sectors receiving targeted support in the framework of the regionally decentralized programs. Otherwise, the support programs have become practically identical in all regions. "This made the process of regional innovation policy implementation more efficient and easier to manage and administer." (Interview with an NIO official).

The next milestone in the process of suppressing the regional decentralization of innovation was the government's effort to channel regional applications away from regionally decentralized programs ${ }^{8}$ and towards centrally managed Operational Programs (OPs), by prescribing ever stricter conditions to gain support from the former program type. The national government gradually withdrew from funding regional innovation undertakings using regionally decentralized sources. The final calls for proposals under innovation support programs funded from regionally decentralized sources were in 2009. Subsequently, regionally earmarked grants from EU Structural Funds channeled through Operational 
Programs have become the only region-specific source of funding innovation activities. Regional Operational Programs cannot, however, be considered regionally decentralized sources of funding since program design, project selection, financial management, monitoring and evaluation are all under the central/national authority.

Parliamentary elections in 2010 brought about changes in the structure of OPs that further reversed the regionalization of innovation (and of development). Regional OPs were merged into the newly established functional OPs, such as the Science \& Innovation, Green Economy, and Health Industry Programs.

As of 2010, RIAs received no more budgetary funding to cover the costs of their public benefit activities (in the 2000s, their activity was funded from national sources). The traditional institutional instability that characterizes the Hungarian innovation and public administration systems was exacerbated following the parliamentary elections in that same year.

Responsibility for the allocation of funding from the Research and Technological Innovation Fund was then transferred from the National Innovation Office to the National Development Agency. The National Innovation Office was hollowed out and the majority of experts fired, in a manner similar to all other institutions of public administration and territorial development. Personnel changes involved not only the top management of the previous political cycle but also desk level officials. The implementation of innovation-related programs was frozen: new calls for proposals were not announced for more than a year. Existing contracts (signed during the period of the previous government) underwent a lengthy review process. Payment of contracted support was frozen or waived.

The National Development Agency became subordinated to a newly established ministry - the Ministry of National Development. Shortly thereafter, it was transferred under the authority of the Prime Minister's Office (government decree 273/2013) and then six months later, dissolved (government decree 475/2013). Responsibility for the management and implementation of individual, innovation-related OPs was dispersed and transferred to various ministries: to the Prime Minister's Office; the Ministry for National Economy; the Ministry of National Development; and the Ministry of Human Resources.

This fundamental restructuring of regional development culminated in the creation of the National Development Steering Committee (NDSC) to speed up the absorption of EU Structural Funds. ${ }^{9}$ NDSC has four members: Prime Minister (who plays the leading role), ministers for national development and the economy, and the state secretary in charge of the Prime Minister's Office. Decisions on large-scale developmental projects and all innovation related programs (funded from Research and Technological Innovation Fund, or from OPs) rests with the NDSC (government decree 140/2012).

This lengthy (albeit far from comprehensive) enumeration of institutional and regulatory changes documents the mechanism that has brought about state capture in Hungary, where funding is based on political loyalty, rent-seeking and clientelism [cf. Ágh, 2013]. ${ }^{10}$ Key elements of this mechanism are the firing of experts, over-politicization of public 
administration, dissolution of existing institutions and creation of new ones; frequent redistribution of authorities and responsibilities leading to institutional chaos; and a parallel centralization of power with respect to decisions that affect private gains. Paradoxical as it may seem, institutional instability and centralization have been going hand in hand, reinforcing each other in a 'virtuous circle'.

The centralization of territorial development reached a tipping point just at the time of the official reform of EU Cohesion Policy. A key component of the reform is the incorporation of smart specialization in national and regional innovation strategies.

This coincidence is important, since smart specialization is closely related to the concept of partnership, empowerment of local stakeholders, decentralization and bottom-up approaches - given its strong reliance on local competitive strengths, the identification of which requires the involvement of local stakeholders. Smart specialization necessitates mutual learning and experimentation, continuous interactions and evidence-based feedbacks and adjustments.

It is therefore obvious that the concentration of power that characterizes Hungarian territorial development contradicts all elements of the smart specialization concept. The context of a 'single-actor governance system' notwithstanding, compliance on paper has been impeccable: all Hungarian RIAs prepared the RIS3 strategies of their regions within a timeframe of four to six weeks: they creatively re-worded the existing innovation strategies along 'new ideological lines'. The Ministry for National Economy synthesized these regional strategies and drafted a national-level smart specialization strategy designated to become part of the EU - Hungary Partnership Agreement for the programming period of $2014-2020$.

While programming (strategy drafting) has been accomplished in full compliance with EU prescriptions, the claim that adaptation was formalistic and cynical is best substantiated by the fact that strategy design and implementation (in terms of funding allocation) are worlds apart. Regional planning and programming have no influence on the content of innovation related policy instruments and support programs. These latter are uniform across regions, which contradicts the concept of smart specialization. Even less commonalities can be found between RIS3 strategies and the selection of support beneficiaries.

In the context of a non-existing regional devolution of policy implementation and no regionally decentralized innovation support measures, RIS3 related activities such as planning, programming, social consultancy (involving local stakeholders in the programming process), - however exemplary - can be considered only a kind of façade regionalism, façade smart specialization.

Hence, in addition to the impact of EU integration, it seems necessary to analyze other factors that influence Hungarian innovation performance. The next sections explore the impact of Hungarian actors' integration in global value chains (GVCs). 


\section{Impact of FDI and GVC-Integration: Sample of Interviewed Companies}

Hungary's strong reliance on FDI-driven growth and modernization has made Hungary highly integrated in global value chains. According to De Backer and Miroudot [2012] who quantified countries' GVC-participation indices, ${ }^{11}$ the Czech Republic shows the highest GVC integration out of 33 OECD-economies (with an indicator slightly above 65\%). Slovakia and Hungary rank fourth and fifth, respectively, with values slightly below $65 \%$ (p. 7).

Although Hungary has already lost its FDI attraction frontrunner status [Csáki, 2001], FDI stock as a percentage of Hungary's GDP is still among the highest in Europe (81.7\% in 2012, as compared to $69.6 \%$ and $47.3 \%$, respectively, for the Czech Republic and Poland [UNCTAD World Investment Report, 2013]. Following initial market-seeking investments in the 1990s, efficiency-seeking FDI has become dominant [Sass-Kalotay, 2012]. Relatively large FDI stocks characterize the electronics and transport equipment industries. Foreign-owned enterprises accounted for $66.2 \%$ of total manufacturing value added in 2011. Their share in total sales was above $95 \%$ in the electronics and transport equipment industries and above $85 \%$ in the machinery and electrical equipment industries (source: Central Statistical Office). The prominent role of foreign-owned enterprises is also reflected by their share in gross fixed capital formation; in 2011 it was $76.4 \%$ in manufacturing [Central Statistical Office].

FDI-promotion policies gradually shifted their focus from quantity to quality-based considerations [Antalóczy et al., 2011]. Expectations towards foreign investors have turned increasingly sophisticated and variegated. Selective incentives have been applied to encourage existing investors to co-locate high value adding activities to their local production facilities, especially production-related R\&D. Support programs also aimed at enhancing foreign investors' local backward linkages, and local embeddedness has been promoted through policy measures fostering clustering and collaboration with local universities and public research organizations.

The author of this paper interviewed 15 large manufacturing MNCs' R\&D-intensive Hungarian subsidiaries in the automotive and electronics industries; specifically, 9 automotive and 6 electronics companies. The share of foreign investors in total $\mathrm{R} \& \mathrm{D}$ expenditures is above the average in the two surveyed industries [Dachs et al., 2012].

Research was carried out between mid-2011 and 2013. Research questions addressed subsidiaries' R\&D-based upgrading experience and drivers of the upgrading process. ${ }^{12}$ Interview questions are presented in the Annex of this paper. ${ }^{13}$

Given the qualitative nature of our research questions, we used a case study based investigation method [Yin, 2003], employing a semi-structured questionnaire containing open-ended questions. We interviewed either the CEOs or various functional managers 
of the selected subsidiaries, including the chief procurement officer (two cases), the chief information officer (one case), the chief communication officer (two cases), the chief technology officer (two cases), and the manufacturing operations manager (one case). The interviews lasted 45 to 90 minutes (depending on the willingness of the interviewee to expound on details). As the interviewed firms required anonymity, neither their names will be disclosed nor their main products specified.

We selected large, ${ }^{14} 100 \%$ foreign-owned, ${ }^{15}$ export-oriented, ${ }^{16} \mathrm{R} \& \mathrm{D}$-intensive ${ }^{17}$ subsidiaries. For each firm, interview information was complemented with such documents as newspaper articles, firm information brochures, and publicly available balance sheets, profit and loss statements, and official 'notes to the financial statement'.

\section{Impact of GVC-integration on Hungarian Actors' Knowledge- -Based Upgrading -Interview Findings}

We briefly summarize the key findings of our interviews below. The purpose of doing so is not to provide a detailed account of the surveyed subsidiaries' R\&D-based upgrading. Interview findings are instead compiled here to substantiate our second theme, that GVC-integration is the key factor driving knowledge-based upgrading in Hungary.

The first important finding of our investigation was that, over time, the product mix of virtually every surveyed companies underwent non-negligible changes; or rather, non-negligible development. Besides locating increasingly sophisticated products (that often required substantial tangible investment by the owners in new production equipment, i.e., in technology development), local subsidiaries also co-evolved with their parent companies. This was particularly pronounced when local firms had responsibility for producing their MNC-owners' newly developed products. Each new product launch ${ }^{18}$ involved local process development activities, while gaining a new product mandate (which was subject to inter-subsidiary competition) required local engineers' production planning (plant layout planning) efforts and their development of technological solutions.

We found that over time, local production related support $\mathrm{R} \& \mathrm{D}$ activities were invariably co-located to the surveyed MNCs' manufacturing facilities, as production 'pulled' development activities. Initially, R\&D activities were confined to routine problem-solving and testing tasks. Eventually, however, more skill-intensive, higher value-added process development activities were entrusted to the subsidiaries that managed to convince their owners about their capabilities.

It became evident that among offshored business functions, R\&D offers the longest upgrading trajectory for catching-up peripheral subsidiaries. The 'quality ladder' of $\mathrm{R} \& \mathrm{D}$ activities is quite long, since $\mathrm{R} \& \mathrm{D}$ functions can be decomposed into a multitude of activities that feature different skill intensities and value adding capabilities [Schmitz-Strambach, 2009]. 
Upgrading within the R\&D function may proceed along the extensive margin, with the take-up of additional tasks, and/or along the intensive margin, which refers to the increasing complexity of the $\mathrm{R} \& \mathrm{D}$ tasks with which local subsidiaries are entrusted. Moreover, R\&D activities may evolve in scope if high-performing local subsidiaries are entrusted with $R \& D$ tasks that support the subsidiary's local production function and perform R\&D activities that add value to partner subsidiaries and/or headquarters (MNC-level $\mathrm{R} \& \mathrm{D}$-activities). Upgrading within the R\&D function may culminate in world product mandates (when a subsidiary gains responsibility for all development activities related to a specific product in the MNC's portfolio).

Although there were several companies in our sample (4 out of 15) that were stuck in relatively low-level $\mathrm{R} \& \mathrm{D}$ activities, most of them managed to enhance the complexity of the R\&D activities (though a sample selection bias may apply). ${ }^{19}$ Subsidiaries gained additional tasks in process, in product, tool, and process- or product-related software development, as well as testing, product adaptation, and design.

In addition to the co-location rationale (according to which problems should be solved 'at source', as they arise [Lanz et al., 2011]) investors considered the wage differences between home and host country scientists and engineers an important factor that motivated their R\&D internationalization decision.

The interviewed subsidiaries were quite successful in accessing public support (co-financed from EU Structural Funds) that had been earmarked for R\&D activities. However, the interviewed managers were unanimous in claiming that public support did not prompt owners to carry out R\&D activities at their local subsidiaries (or extend and deepen existing R\&D activities); rather, such support was a catalyst that accelerated the owners' earlier decision to upgrade local subsidiaries and co-locate some R\&D activities to the premises of production. This view was at least partially corroborated by the fact that support applications were submitted after a systematic evaluation of costs and promised benefits of investment into local R\&D activities, and only in cases when these evaluation exercises yielded positive results.

\section{Lessons and Conclusions}

In this paper we argue that EU membership has not provoked cogent transformations in the features and efficiency of the Hungarian national innovation system. Economic actors' integration into global value chains has more effectively contributed to knowledge-based upgrading, though the allocation of funding from Structural Funds to multinational companies' local subsidiaries seems to have effectively accelerated this latter process.

It must be acknowledged that our approach has limitations, such as the relatively short survey period (insofar as changes in a country's innovation system take a long time to 
become manifest in improved performance), and the small number of firms interviewed (a 15-firm-sample does not allow for general conclusions).

Another limitation is the subjective character of our assessment, given that the Hungarian experience is analyzed in isolation. It is fair to suppose that other new member states have not shown significantly better NIS-evolution dynamics following EU accession. It is up to future research to compare the efficiency of other new member states' national innovation systems.

These limitations notwithstanding, important 'telling' indicators have not changed, including: (1) the enduring dominance of foreign companies in gross fixed capital formation in manufacturing; (2) the high share of foreign companies in total private R\&D outlays (see footnote 4); and (3) the low efficiency of public funds in generating innovation-driven growth, together with the prevalence of local subsidiaries' co-evolution with their mother companies in terms of functional upgrading and taking up R\&D activities. It therefore seems self-evident that the major channel of improving innovation performance is through MNCs' relevant activities.

Moreover, it has to be borne in mind that R\&D activities carried out within MNCs' organizations will per definitionem forestall commercialization-related problems. The results of subsidiaries' R\&D activities will be used by the MNC-owners, or a market for subsidiaries' innovation results will be ensured by the MNC-owners.

Although it is relatively easy to pick individual success stories with respect to foreign investment in $\mathrm{R} \& \mathrm{D}$, and local manufacturing subsidiaries' $\mathrm{R} \& \mathrm{D}$-based upgrading, excessive reliance on foreign investors has real drawbacks. Since the volume and the quality of domestic R\&D capital stock are highly important determinants of foreign R\&D investment [see, e.g., Erken and Kleijn's econometric exercise, 2010, and a literature survey by Ambos and Ambos, 2011] the poor overall innovation performance of Hungarian indigenous firms cannot be countered by individual success stories of MNC subsidiaries' R\&D-based upgrading. A near-exclusive reliance on foreign investment with respect to BERD greatly reduces the multiplier effect of foreign investments into R\&D. Furthermore, sporadic individual success stories of $\mathrm{R} \& \mathrm{D}$-based upgrading usually remain below the critical mass, failing to push specific industries or regions to a knowledge-based growth trajectory.

Recently, however, the indicator 'number of indigenous innovative companies' started to increase and the 'share of companies with no innovative activities' diminished. ${ }^{20}$ These are clear-cut positive effects of EU membership. But these indicators have not necessarily improved as a result of indigenous companies' capacity building: their upswing may be simply a statistical illusion, explained by the fact that a large number of companies have received support from EU Structural Funds earmarked for R\&D activities. In consequence, recipient companies report that they carry out innovative activities. Note that the boundaries between 'no innovative activities' and 'some kind of innovation' are quite elusive, and depend on the discretionary assessment of the managers that fill the CIS-questionnaires. ${ }^{21}$ 
Consequently, the absorption of EU Structural Funds that target innovation does not necessarily lead to improved, innovation-based economic performance: more innovative activities will be performed, but their economic impact remains to be seen.

\section{Notes}

${ }^{1}$ According to the classification of the Innovation Union Scoreboard [2014], Hungary's position is of a 'moderate innovator,' though three of its seven regions are modest innovators.

${ }^{2}$ Hungary's SII has been steadily growing since the mid-2000s (up to 0.351 in 2013) but it is still far below the EU-average of 0.554 (Source: Innovation Union Scoreboard 2014, p. 92). According to CsukaTörök [2014], Hungary's innovation performance is broadly in line with its development level. Over the past decade its position within the EU (measured by SII rankings) has not significantly worsened, which is in marked contrast to Hungary's substantially deteriorating comparative economic performance. See also Török [2008] about rankings and the relation between science, innovation and macroeconomic performance.

${ }^{3}$ According to Pitti's [forthcoming] calculations from data of the National Tax Authority, the ratio of value added to gross output in the Hungarian electrical and optical equipment industry was a mere $12.7 \%$ in 2012 ( $11 \%$ in 2007); in the transport equipment industry, $19.9 \%$ in 2012 (18.6\% in 2007 and $22.7 \%$ in 2010$)$.

${ }^{4}$ According to Pitti's [2010] calculations from the data of the National Tax Authority, in the second half of the 2000s, the share of foreign investors in total business enterprises financed R\&D outlays was between 85 and $90 \%$. According to CSO-data, in 2012 50.9\% of total researchers working in corporate $\mathrm{R} \& \mathrm{D}$ departments worked in foreign-owned companies. There is a marked discrepancy between CSO and Tax Authority data with respect to the share of foreign owned companies within total business enterprise financed R\&D outlays; according to Tax Authority data, foreign investors' share is by $\sim 25-30 \%$ higher, amounting to 85 or $90 \%$ of the total.

${ }^{5}$ Edler [2011], compared the development level of demand conditions for innovation in CEE countries based on the World Economic Forum's large-scale survey of business leaders' subjective assessments. He found that buyer sophistication (inclination and ability of buyers to select products based on performance rather than price and, thus, their willingness to purchase innovative products) is the lowest in Hungary. According to business leaders' perceptions, the impact of public procurement on innovation and technology generation is the smallest, and practically non-existent, in Hungary. Corruption, bribery, and government favoritism in public purchasing decisions is high. Note that Edler analysed the 2008-2009 edition of the World Competitiveness Report; since then the situation has significantly deteriorated in Hungary. One example, by way of illustration, concerns buyer sophistication. From placing $95^{\text {th }}$ out of 134 countries in 2008-2009, Hungary slid to the $125^{\text {th }}$ place by 2013-2014 out of 148 countries (the Czech Republic is $75^{\text {th }}$, Poland is $93^{\text {rd }}$ ).

${ }^{6}$ For details see the RIS3 Guide issued by the European Commission (http://s3platform.jrc.ec.europa. eu/ s3pguide). See also: Foray et al., 2009; 2011;

${ }^{7}$ Up till 2011, the name of the Office was National Office for Research and Technology.

8 Initially, regionally decentralized programs were more popular than EU co-financed, centrally announced operational programs targeting innovation, mainly because the former programs required relatively little co-financing by recipients and advance payments were available. By contrast, the required 
level of beneficiary co-financing in the case of operational programs is often above $50 \%$. Moreover, regionally decentralized programs were much simpler to administer, whereas OP-support imposed a substantial administrative burden on beneficiaries.

${ }^{9}$ According to the data of the Regional Innovation Scoreboard [2014],Hungary was found to have the lowest absorption rates (p. 30), which is explained by institutional instability and frozen / waived programs.

${ }^{10}$ Note that in contrast to the distinction applied by Innes (2014), who distinguished between 'party state capture' (aiming to monopolize political power) and 'corporate state capture' (exercised mainly for private gains), Hungary represents a combination of these two ideal types.

11 Going beyond the simple import content (or rather foreign value added content) of exports, the GVC Participation Index contains foreign value-added and domestic value-added used in third country exports (as a share of gross exports in percentages). Thereby, it captures the downstream side of integration, i.e., the value of inputs exported to third countries that will, in turn, be used in these countries' exports.

${ }^{12}$ Research was funded by the Hungarian National Research Fund [OTKA K83982]. Some interviews were carried out in collaboration with Magdolna Sass, who also received financial support from EU FP7 "Growth-Innovation-Competitiveness: Fostering Cohesion in Central and Eastern Europe" [GRINCOH]. Section 5 of the paper draws partly on Sass-Szalavetz [forthcoming]; and on Szalavetz [2013].

13 The findings presented in this paper are the outcome of two large-scale research undertakings, each of which addressed a number of topics that influenced the surveyed firms' upgrading experience and performance. The list of interview questions in the Annex contains only the questions that are relevant for this paper's focus.

${ }^{14}$ In 2012, the average number of employees at the surveyed firms was 1,321 and average sales were EUR 186.6 million. The sample was selected from the authors' database of case studies and journal articles on the activities of Hungarian subsidiaries in the chosen sectors. This sample selection method poses the risks of selection bias: our sample consists of well-known 'blue chip' companies that may show above-average upgrading performance.

15 The sample included subsidiaries of German, French, Danish, American, Mexican and Japanese MNCs.

16 The average share of exports in total sales was $87.7 \%$ in 2012 .

17 The average number of R\&D staff was 23 (2012). Most of the interviewed companies refrained from disclosing the share of R\&D outlays in total sales.

${ }^{18}$ According to the terminology used by innovation economics scholars, new product launch refers to products that are new to the local subsidiary, while new a product mandate refers to new to the world (new at MNC-level) products.

${ }^{19}$ When inquiring about the evolution of the 'depth' (complexity) of R\&D tasks, we applied measurement constructs advanced by Taggart [1998], measuring the quality and the complexity of R\&D activities with their average timeframe, i.e., with the time that elapses until the given research undertaking is expected to bear fruit. Routine, problem solving R\&D tasks have a timeframe of a several hours or days. The timeframe of engineering support tasks (including applied engineering for the launch of new products, quality management, process optimization, minor product improvements etc.) ranges from several weeks to several months. The more advanced an R\&D task is (e.g., software development, design, new product development) the longer time is allocated for the project before the first results can be expected.

${ }^{20}$ Data will be available only within one or two years, since this indicator is quantified by bi-annual CIS-surveys.

${ }^{21}$ Considering the broad conceptualization of innovation it is fair to report innovative activities even in cases when innovation is confined to investment in new machinery, the installation of which requires process development, adaptation etc. Hence, purchases of new production technology (the action that was supported by EU Structural Funds) represent process innovation. As for product innovations, Inzelt and Szerb's [2006], finding that in lagging regions this kind of innovation usually denotes minor changes in the product parameters that do not improve the given firm's export potential still applies - a decade later. 


\section{References}

Ágh, A. (2013), Bumpy Road of the Hungarian Administrative Reforms: From Political Over-Centralization to Public Policy Failures. Croatian \& Comparative Public Administration, 13(4), pp. 1115-1136.

Ambos, B., Ambos, T.C. (2011), Meeting the Challenge of offshoring R\&D: an examination of firm- and location-specific factors. R\&D Management, 41(2), pp.107-119.

Antalóczy, K., Sass, M., Szanyi, M. (2011), Policies for attracting foreign direct investment and enhancing its spillovers to indigenous firms. in: Rugraff, E., Hansen, M.V. (eds.), Multinational Corporations and Local Firms in Emerging Economies. Amsterdam, Amsterdam University Press, pp. 181-209.

Bachtler, J., Mendez, C., Oraže, H. (2013), From Conditionality to Europeanization in Central and Eastern Europe: Administrative Performance and Capacity in Cohesion Policy. European Planning Studies, DOI: 10.1080/09654313.2013.772744.

Bruszt, L. (2008), Multi-level governance - the Eastern versions: emerging patterns of regional developmental governance in the new member states. Regional and Federal Studies, 18(5), pp. 607-627.

Buzogány, A., Korkut, U. (2013), Administrative Reform and Regional Development Discourses in Hungary. Europeanisation Going NUTS? Europe-Asia Studies, 65(8), pp. 1555-1577.

Csáki, Gy. (2001), The inflow of foreign direct investment into Hungary, in Csáki, Gy. \& Karsai, G. (eds.), From Transition to Integration. Macroeconomic Development in Hungary 1990-2002. New York, Columbia University Press, pp. 226-261.

Csuka, Gy., Török, Á. (2014), Hungary in international innovation competition - following EU accession. [Magyarország a nemzetközi innovációs versenyben az EU-csatlakozás után.] Közgazdasági Szemle, 61(4), pp. 509-526.

Dachs, B., Hanzl-Weiss, D., Kampik, F., Leitner, S. Scherngell, T., Stehrer, R., Urban, W., Zahradnik, G. (2012), Internationalization of business investments in $\mathrm{R} \& \mathrm{D}$ and analysis of their economic impact. Mimeo, Available at: http://www.observatory.org.gr/Portals/0/Vivliografia/31.internationalisation_business-rd_analytical -report. pdf

De Backer, K., Miroudot, S. (2013), Mapping global value chains. Mimeo, http://www.wiod.org/conferences/ groningen/Paper_DeBacker_Miroudot.pdf

Edler, J. (2011), Innovation in EU CEE: the role of demand-based policy, in: Radosevic, S. \& Kaderábková, A. (eds.), Challenges for European Innovation Policy: Cohesion and Excellence from a Schumpeterian Perspective, Edward Elgar Publishing., pp. 177-208.

Erken, H., Kleijn, M. (2010), Location factors of international R\&D activities: an econometric approach, Economics of Innovation and New Technology, 19(3), 203-232.

European Commission (2013), Research and innovation performance in EU member states and in associated countries. Innovation Union progress at country level, 2013. Brussels: European Commission. Available at: http://ec.europa.eu/research/innovation-union/pdf/state-of-the-union/2012/innovation_union_progress_at_ country_level_2013.pdf

Foray, D., David, P.A., Hall, B. (2009), Smart specialization-the concept. Knowledge Economists Policy Brief, 9. Foray, D., David, P.A., Bronwyn, H. (2011), Smart specialization. From academic idea to political instrument, the surprising career of a concept and the difficulties involved in its implementation. Management of Technology and Entrepreneurship Institute Working Paper, No. 1. 
Gál, Z. (2013), National - regional conflicts in innovation governance - Central and regional governance of innovation in Hungary. [A régiók és az állam konfliktusai az innovációs kormányzásban - Az innováció központi és regionális irányítása Magyarországon.] Közép-Európai Közlemények, 6(1-2), pp. 294-309. Available at: http:// open-archive.rkk.hu:8080/jspui/bitstream/11155/324/1/gal_regiok_2013.pdf

Havas, A. (2007), Escaping from the Nutcracker? Innovation Policy in Hungary. In: K. Piech (Ed.), Knowledge and innovation processes in Central and Eastern European economies, Warsaw: The Knowledge and Innovation Institute, pp. 126-148.

Havas, A. (2011), The performance of the Hungarian national innovation system. Conference presentation. Available at: http://www.econ.core.hu/file/download/sebawsh/HAVAS.pdf

Innes, A. (2014), The political economy of state capture in central Europe. Journal of Common Market Studies, 52(1), pp. 88-104.

Inzelt, A., Szerb, L. (2006), The Innovation Activity in a Stagnating County of Hungary. Acta Oeconomica, 56(3), pp. 279-299.

Izsák, K., Markianiodi, P., Radosevic, S. (2013), Lessons from a Decade of Innovation Policy. European Commission, DG Enterprise and Industry, Available at: http://www.technopolis-group.com/wp-content/uploads/2014/05/1720_Lessons-from-ten-years-of-innovation-policies-.pdf

KPMG (2013), Evaluation of the Economic Development Programme’s RTDI interventions. [Értékelés a gazdaságfejlesztési program kutatás-fejlesztés és innovációt célzó beavatkozásairól.] prepared for the National Development Agency, in Hungarian.

Langford, C.H., Hall, J., Josty, P., Matos, S., Jacobson, A. (2006), Indicators and outcomes of Canadian university research: Proxies becoming goals? Research Policy, 35(10), pp. 1586-1598.

Lanz, R., Miroudot, S., Nordås, H.K. (2011), Trade in Tasks. OECD Trade Policy Working Papers, No. 117, OECD Publishing, http://dx.doi.org/10.1787/5kg6v2hkvmmw-en.

Montalvo, C. \& Moghayer, S. (2011), State of an innovation system: theoretical and empirical advance towards an innovation efficiency index. MPRA Paper, No. 38002, Available at: http://mpra.ub.uni-muenchen.de/38002/1/ MPRA_paper_38002.pdf

Pálné Kovács, I. (2009), Regions and developmental coalitions. [Régiók és fejlesztési koalíciók]. Politikatudományi Szemle, 18(4), pp. 37-60.

Pálné Kovács, I. (2013), Why did we let it happen? The specifics of reforms aiming at territorial decentralization in Hungary. [Miért hagytuk, hogy így legyen?: A területi decentralizációs reformok természetrajza Magyarországon.] Available at: http://regscience.hu:8080/jspui/handle/11155/346.

Pitti, Z. (forthcoming). Economic performance viewed from below 2007-2012. [Gazdasági teljesítmények alulnézetből, 2007-2012]. Mimeo (in Hungarian).

Pitti, Z. (2010), The domestic and the international business sphere before and after the crisis. [A hazai és nemzetközi vállalati szféra a válság elött és után.] Mimeo PPT presentation.

Pop Silaghi, M.I., Alexa, D., Jude, C., Litan, C. (2014), Do business and public sector research and development expenditures contribute to economic growth in Central and Eastern European Countries? A dynamic panel estimation. Economic Modelling, 36, pp. 108-119.

Reid, A. (2011), EU innovation policy: one size does not fit all! In: Radosevic, S. \& Kaderábková, A. (Eds.), Challenges for European Innovation Policy: Cohesion and Excellence from a Schumpeterian Perspective, Edward Elgar Publishing., pp. 112-149. 
Sass, M. (2013), Case Study Evidence of the Extent and Nature of Foreign Subsidiaries' R\&D and Innovation Capability in Hungary. Mimeo, prepared in the framework of EU FP7 "Growth-Innovation-Competitiveness: Fostering Cohesion in Central and Eastern Europe” (GRINCOH). Available at: http://real.mtak.hu/8422/1/ Grincoh_Sass.pdf

Sass, M., Kalotay, K. (2012), Inward FDI in Hungary and its policy context. New York: Vale Columbia Center on Sustainable International Investment, Available at: http://www.vcc.columbia.edu/content/columbia-fdiprofiles.

Sass, M., Szalavetz, A. (forthcoming), R\&D-based integration and upgrading in Hungary. Acta Oeconomica, [forthcoming].

Schmitz, H., Strambach, S. (2009), The organizational decomposition of innovation and global distribution of innovative activities: insights and research agenda. International Journal of Technological Learning, Innovation and Development, 2(4), pp. 231-249.

Szalavetz, A. (2013), Upgrading within MNCs' global value chains. Experience of Hungarian subsidiaries. [Feljebb lépés a multinacionális vállalatok globális értékláncain belül - a hazai leányvállalatok tapasztalatai.] Külgazdaság, 57(1-2), pp. 66-91.

Taggart, J.H. (1998), Determinants of increasing R\&D complexity in affiliates of manufacturing multinational corporations in the UK. R\&D Management, 28(2), pp. 101-110.

Török, Á. (2008), Science or competitiveness? Science and competitiveness! Public Finance Quarterly, 53(4), pp. 557-579.

Yin, R.K. (2003), Case Study Research: Design and Methods, 3rd Edition, Thousand Oaks, CA.: Sage Publications.

\section{Appendix}

\section{Interview report}

Note: This Appendix contains only some of the questions asked in the framework of two large-scale research undertakings: only the questions relevant for this paper's focus are listed below.

1. Basic company data

- Name and address (city only)

- Main products

- Ownership

- Sales

- Share of exports in total sales

- Employment

- Number of R\&D-staff

- (Approximate) share of R\&D outlays in total sales

2. Activity and evolution of activity portfolio

- What is the core activity of the company? 
- Has the knowledge-, technology- and skill-intensity of the core activity increased since the establishment of the Hungarian subsidiary?

- Has the product mix changed/evolved over time?

- Did the above-mentioned changes require any tangible investment (purchase or relocation of new machinery) and any specific training from the part of both the blue and white-collar staff? Please explain the specifics of the learning process!

- Is the company engaged in any production specific support activities? Please list them and explain how the (support) activity portfolio of the company evolved!

3. $R \& D$ activities

- Please provide some details about the specifics and the evolution of R\&D activities!

- Explain how the local management convinced the parent company's management to locate R\&D activities to Hungary! What do you think the owners' motivations were in this respect?

- Could the local subsidiary benefit from any government support with respect to $\mathrm{R} \& \mathrm{D}$ and/or investments in new technology? Did you apply for support?

- What is your opinion about national/regional business/innovation promotion opportunities in Hungary?

4. R\&D-specific linkages, innovation collaboration

- Do you collaborate with any local, regional or national higher education institutions and/or research organizations? Please provide some details about the specifics of this collaboration!

- Are you member of a cluster? What was the main motive of your cluster membership? What are the key benefits of your cluster membership?

- Do you outsource any R\&D-specific activity to Hungarian actors? 